\title{
The Reach of Curriculum Reform of "Fuel Feeding and Electronic Control System of Diesel Engine" Based on Working Process
}

\author{
Yan CHENG \& Zhizhong LIU \\ Hebei Jiaotong Vocational \& Technical College, Hebei Province, China
}

\begin{abstract}
The Fuel Feeding and Electronic Control System of Diesel Engine" is one of core curriculums of Automobile Detection and Maintenance Specialty. In view of the problems in traditional teaching of Diesel Engine, we design reasonably 7 teaching circumstances, teaching methods and the evaluation mode of this curriculum to improve students' professional quality according to the selection of 7 domestic typical electronic control and assistant control systems for Diesel Engine and common maintenance process of these systems.
\end{abstract}

KEYWORD: based on working process; Diesel engine; curriculum reform

\section{INTRODUCTION}

The production and sales of electronic control diesel engine is rising for its high fuel-efficient, durable and low-emission both in domestic and foreign market. A large number of engineering machine equipped with electronic control diesel engine are used to build infrastructure in China recent years. So the courses related to electronic controlled diesel engine will become one integral part of automobile and engineering machine professional education.

\section{EXISTING PROBLEMS}

\subsection{The content of the course is outmoded}

Since China implemented National Motor Vehicle Pollutant Emission Standard of Third Stage (GB18352.3-2005) in 2008, laggard mechanical fuel system of Diesel engine was eliminated rapidly. However, the related content of mechanical fuel supply system still accounted for more than 50\% hours in the process of teaching. It not only do not meet the job requirements, but also make students be baffled for complex principle and influence the teaching effect of subsequent teachings of electronic control system.

At the same time, class hours of electronic control system are so insufficient that the knowledge students can get is superficial and narrow, students find it difficult to grasp the skills of testing and fault diagnosis, lack of understanding of the new technology as acceptable. This leads to the ability of the graduates decoupling from the needs of society, and will affect the students' employment.

\subsection{The lack of new training equipment}

The diesel engine curriculum is a subordinate part of little importance to the engine curriculum system for a long time. It result in fewer production of teaching aids and training equipment for electronic control system of diesel engine; electronic control system of Diesel engine is with high precision, so it is expensive; all these reasons lead to shortage of simulation laboratory worktable, detection and repair equipment, physical teaching training equipment, and affect the teaching effect seriously.

\section{CURRICULUM REFORM}

\subsection{Curriculum Nature}

"Fuel Feeding and Electronic Control System of Diesel Engine" is a professional core curriculum of Automotive Engineering Department of Hebei Jiaotong Vocational \& Technical College. Based on post ability analysis for auto mechanics and related occupation jobs, we construct and implement this learning field curriculum according to advanced curriculum development theory based on working process.

The goal of this course is enable students to master professional ability for electronic controlled fuel injection system(Common Rail, Unit Pump, Unit Injector) and its auxiliary system(EGR, VGT, Intake Air Preheating, Intake Flap, etc). This course is based on the course "Detection, Diagnosis and Repair of Engine Mechanical System". Follow-up courses are "Automotive Bus Technology" and "Automobile Maintenance". 


\subsection{The content of course}

We set the content of "Fuel Feeding and Electronic Control System of Diesel Engine" according to market status of Chinese electronic controlled Diesel Engine:

(1) Brief introduction of the combustion process, the working principle of diesel, analyzing the similarities and differences between the diesel engine and gasoline engine process, overview the working principle of mechanical fuel supply system;

(2)The vast majority of Chinese electronic controlled fuel injection systems of diesel engine are common rail systems, so we set related knowledge and training skill of the common rail systems produced by Germany Bosch, Japanese Denso and American Delphi and met National Motor Vehicle Pollutant Emission Standard of Third Stage as the main teaching content;

(3)Summary of typical electronic unit pump system;

(4)Set the latest technology of electronic controlled diesel engine, such as the third and fourth generation common rail system and exhaust aftertreatment technologies (SCR, PDF) etc, as "Advanced Contents". On the teaching method of this part, it combines classroom instruction with student teaching oneself together.

(5)Electronic controlled unit injector system is rare in Chinese diesel engine, so we set this part as "Self-learning Contents". Teachers are responsible for answering questions.

(6)In accordance with the provisions of relevant Chinese policies, automobile maintenance industry require permitting qualification strictly for practitioners, therefore, we add the knowledge related to auto mechanic occupation qualification examination(three level) into the content of course.

(7) According to corporate research, we found that the mechanics who can really understand the circuit diagram are so rare that the circuit manual cannot play its due role. So we pay particularity attention to enhance students' ability of reading circuit diagrams in whole teaching process.

\subsection{Teaching circumstances design}

Through investigation, we take 7 typical electronic controlled diesel engine in China as examples, set the electronic controlled high-pressure common rail system and its auxiliary system as the main teaching content, the unit pump system as the minor content. On the basis of common maintenance processes of electronic controlled diesel engine and following the basic law of cultivating vocational ability, We design 7 teaching circumstances which including 22 maintenance projects. Models for example are listed in Table 1, detailed teaching arrangement is shown in Table 2.

Table 1. Selected models

\begin{tabular}{|l|l|}
\hline \multirow{4}{*}{$\begin{array}{l}\text { Passenger } \\
\text { Car }\end{array}$} & $\begin{array}{l}\text { GREATWALL GW2.8TC Bosch Common Rail } \\
\text { System Diesel Engine }\end{array}$ \\
\cline { 2 - 2 } & HAWTAI Santa Fe D4EA Bosch Diesel Engine \\
\hline \multirow{5}{*}{$\begin{array}{l}\text { Commercial } \\
\text { Vehicle }\end{array}$} & $\begin{array}{l}\text { WEICHAI Bosch Common Rail System Diesel } \\
\text { Engine }\end{array}$ \\
\cline { 2 - 2 } & $\begin{array}{l}\text { YUCHAI Bosch Common Rail System Diesel } \\
\text { Engine }\end{array}$ \\
\cline { 2 - 2 } & $\begin{array}{l}\text { YUCHAI Delphi Common Rail System Diesel } \\
\text { Engine }\end{array}$ \\
\cline { 2 - 2 } & YUCHAI Delphi Unit Pump Diesel Engine \\
\cline { 2 - 2 } & YUCHAI P7100 Unit Pump Diesel Engine \\
\hline
\end{tabular}

Table 2. Teaching Arrangements

\begin{tabular}{|c|c|c|c|c|}
\hline Teaching Circumstance & & Drois & & \\
\hline Section & Content & prioje & & \\
\hline 1.The maintenance of & Diesel engine combustion mechanism; the & 1.1 Piston pump & 2 & \\
\hline mechanical fuel feeding system & principle of mechanical fuel feeding method & 1.2 Bosch VE pump & 2 & \\
\hline 2.Maintenance of electronic & Structure of fuel circuit; maintenance and & 2.1 Maintenance of low pressure line & 6 & \\
\hline $\begin{array}{l}\text { controlled ruel injection system } \\
\text { fuel circuit }\end{array}$ & repair of main components; fuel pressure test & 2.2 Maintenance of high pressure line & 8 & 1 \\
\hline & Installation positions, wiring terminals, & 3.1 Maintenance of position sensors & 2 & \\
\hline 3. Maintenance of sensors and & principles and invalidation strategies of & 3.2 Maintenance of temperature sensors & 1 & \\
\hline switches & $\begin{array}{l}\text { diagnostic trouble codes, data streams and } \\
\text { dictions }\end{array}$ & 3.3 Maintenance of pressure sensors & 2 & \\
\hline & waveforms & 3.4 Maintenance of other sensors and switches & 1 & \\
\hline & $\begin{array}{l}\text { Installation positions, wiring terminals, } \\
\text { principles and invalidation strategies of }\end{array}$ & $\begin{array}{l}\text { 4.1 Maintenance of common rail pressure } \\
\text { regulator }\end{array}$ & 3 & \\
\hline 4. Maintenance of actuators & $\begin{array}{l}\text { pressure regulators and injector solenoid } \\
\text { valves; reading and analyzing diagnostic } \\
\text { trouble codes, data streams and waveforms }\end{array}$ & 4.2 Maintenance of injector solenoid valves & 3 & 6 \\
\hline e of ECU & Reading circuit diagram of ECU; overhaul of & $\begin{array}{l}\text { 5.1Maintenance of the power source of ECU } \\
\text { and ON/ST, ground circuit }\end{array}$ & 2 & \\
\hline electronic & correction code to unit pump's & $\begin{array}{l}\text { 5.2 Matching correction code of injector to } \\
\text { unit pump }\end{array}$ & 2 & \\
\hline
\end{tabular}


Table 2. Teaching Arrangements(continued)

\begin{tabular}{|c|c|c|c|c|}
\hline \multicolumn{2}{|c|}{ Teaching Circumstance } & \multirow{2}{*}{ Project } & \multirow{2}{*}{\multicolumn{2}{|c|}{ Class Hours }} \\
\hline Section & Content & & & \\
\hline \multirow{2}{*}{$\begin{array}{l}\text { 6. Maintenance of } \\
\text { auxiliary systems }\end{array}$} & \multirow{2}{*}{$\begin{array}{l}\text { Construction of EGR, VGT, } \\
\text { preheating and intake flap; } \\
\text { principles of auxiliary systems; } \\
\text { reading and analyzing diagnostic } \\
\text { trouble codes, data streams and } \\
\text { waveforms }\end{array}$} & 6.1 Maintenance of electronic controlled EGR & 3 & \multirow[b]{2}{*}{10} \\
\hline & & $\begin{array}{l}6.3 \text { Maintenance of electronic controlled intake air } \\
\text { preheating }\end{array}$ & 2 & \\
\hline \multirow{4}{*}{$\begin{array}{l}\text { 7. Maintenance } \\
\text { for full details } \\
\text { and common } \\
\text { troubleshooting }\end{array}$} & \multirow{4}{*}{$\begin{array}{l}\text { Maintenance of common rail diesel } \\
\text { engine; reading circuit diagram; } \\
\text { using diagnosis instrument; } \\
\text { common troubleshooting }\end{array}$} & 7.2Troubleshooting of misfire & 4 & \multirow{4}{*}{20} \\
\hline & & 7.3 Troubleshooting of black smoke exhaust & 4 & \\
\hline & & 7.4 Troubleshooting of insufficient power & 3 & \\
\hline & & 7.5 Troubleshooting of unstable idle speed & 3 & \\
\hline
\end{tabular}

\subsection{Teaching Evaluation}

Evaluation is not only a method of testing the achievement of study, but also a means of promoting students learning. To highlight the importance of daily learning, avoid the disadvantages of final review, reflect the quality of students relatively, we adopt the evaluation mode of combining process inspection with terminal theory examination. Detailed assessment method is shown in Table 3.

Table 3. Assessment Method

\begin{tabular}{|c|c|c|c|}
\hline \multicolumn{3}{|l|}{ Process Inspection } & \multirow{2}{*}{$\begin{array}{l}\text { External } \\
\text { Examination }\end{array}$} \\
\hline Usual Performance & Work Sheet & Operation & \\
\hline $20 \%$ & $20 \%$ & $20 \%$ & $40 \%$ \\
\hline
\end{tabular}

(1)Usual Performance: Students get this score from their usual performance, such as observing the discipline, etc.

(2)Work Sheet: This score bases on work sheets students filled in. It is the average of all sheets.

(3)Operation: Check the proficiency, collaboration and independent ability of each student in operation. It is the average of all operations.

\section{CONCLUSION}

Based on the real working processes, we developed the curriculum "Fuel Feeding and Electronic Control
System of Diesel Engine" and received the following achievements:

(1)Students become the main body of learning, their self-study consciousnesses are enhanced effectively. Instead of giving up, they query information, communicate to each other and seek teachers' help actively when they have problems.

(2)Improve the practicable ability. Students operate craftily and efficiently in operation.

(3)Students are confident and proud of solving practical engineering problems independently. The learning process is thus transformed into a virtuous circle.

\section{REFERENCES}

[1] Meng Zhaosheng, Li Hongzhi, ect, 2000. Reaserch and Practice on the Diesel Engine Curriculum Reform. Journal of Heilongjiang Institute of Technology, Vol.14, No.2: 3335.

[2] Feng Chunlin, Zhang Haifeng, 2010. Automotive EFI Diesel Development and Teaching Reform. Journal of Liuzhou vocational \& Technical College, Vol.10, No 1: 85-89.

[3] Tan Yimin, 2014. Structure of Textbook Design Based on the Curriculum Standards. Vocational \& Technical Education Forum, Vol.36: 75-78.

[4] Zhang Xizhen, Tian Youwei, 2007. Electronic Control Technology of Automobile Diesel Engine. Beijing: China Communications Press. 